\title{
$\mathrm{RF}$ Magnetron Sputtering에 의한 $\mathrm{BiFeO}_{3}$ 박막의 제조 및 전기적 특성
}

\author{
박상식 ${ }^{\dagger}$ \\ 경북대학교 나노소재공학부
}

\section{Preparation and Electrical Properties of $\mathrm{BiFeO}_{3}$ Films by RF Magnetron Sputtering}

\author{
Sang Shik Park ${ }^{\dagger}$ \\ School of Nano \& Materials Engineering, Kyungpook National University Sangju, Kyungpook, 742-711, Korea
}

(2009년 2월 25일 접수 : 2009년 4월 17일 최종수정 : 2009년 4월 29일 채택)

\begin{abstract}
Mn-substituted $\mathrm{BiFeO}_{3}(\mathrm{BFO})$ thin films were prepared by r.f. magnetron sputtering under an $\mathrm{Ar} / \mathrm{O}_{2}$ mixture of various deposition pressures at room temperature. The effects of the deposition pressure and annealing temperature on the crystallization and electrical properties of BFO films were investigated. X-ray diffraction patterns revealed that BFO films were crystallized for films annealed above $500^{\circ} \mathrm{C}$. BFO films annealed at $550^{\circ} \mathrm{C}$ for $5 \mathrm{~min}$ in $\mathrm{N}_{2}$ atmosphere exhibited the crystallized perovskite phase. The $(\mathrm{Fe}+\mathrm{Mn}) / \mathrm{Bi}$ ratio decreased with an increase in the deposition pressure due to the difference of sputtering yield. The grain size and surface roughness of films increased with an increase in the deposition pressure. The dielectric constant of BFO films prepared at various conditions shows $127 \sim 187$ at $1 \mathrm{kHz}$. The leakage current density of $\mathrm{BFO}$ films annealed at $500^{\circ} \mathrm{C}$ was approximately two orders of magnitude lower than that of $5500^{\circ} \mathrm{C}$. The leakage current density of the BFO films deposited at $10 \sim 30 \mathrm{~m}$ Torr was about $5 \times 10^{-6} \sim 3 \times 10^{-2} \mathrm{~A} / \mathrm{cm}^{2}$ at $100 \mathrm{kV} /$ $\mathrm{cm}$. Due to the high leakage current, saturated P-E curves were not obtained in BFO films. BFO film annealed at $500{ }^{\circ} \mathrm{C}$ exhibited remnant polarization $(2 \mathrm{Pr})$ of $26.4 \mu \mathrm{C} / \mathrm{cm}^{2}$ at $470 \mathrm{kV} / \mathrm{cm}$.
\end{abstract}

Key words $\mathrm{BiFeO}_{3}$, r.f. sputtering, multiferroic film, leakage current.

\section{1. 서 론}

다강체(multiferroic)재료는 강자성(ferromagnetic)과 강유 전성(ferroelectric)을 동시에 가지는 물질로 메모리 소자 에 응용시 전기 및 자기로 동시에 읽고 쓸 수 있는 장 점이 있어 차세대 메모리 소자로서의 활용이 가능하여 이 에 대한 연구가 매우 활발히 진행되고 있다. ${ }^{1-3)}$ 대표적 인 다강체 물질로는 $\mathrm{BiFeO}_{3}, \mathrm{BiMnO}_{3}, \mathrm{BiCrO}_{3}$ 등의 페 로브스카이트형 산화물들로 두 금속 $\mathrm{A}, \mathrm{B}$ 에 대하여 $\mathrm{ABO}_{3}$ 의 화학 조성을 가진다. 이들은 전자기적 특성이 독 립적으로 나타나지 않고 전기장에 의해 자화 현상의 변 화를 보이며 또한 외부 자기장에 의해 분극 현상을 보 이게 됨으로 넓은 응용 범위를 가질 수 있다. ${ }^{4-6)}$ 다강체 물질 중에서 특히 $\mathrm{BiFeO}_{3}(\mathrm{BFO})$ 는 상온에서 강전자성을 보이는 유일한 물질로 알려져, 많은 연구가 진행중인데 $1103 \mathrm{~K}$ 의 Curie 온도와 $643 \mathrm{~K}$ 의 Neel 온도특성을 보이 며 뒤틀린 능면정(rhombohedral)의 페로브스카이트 구조

Corresponding author

E-Mail : parkss@knu.ac.kr (S. S. Park)
로 결정화되는 특징을 갖는다. ${ }^{7)}$ 따라서 최근에 $\mathrm{BFO}$ 의 박 막성장과 이들의 전기적 성질에 관한 연구가 널리 진행 되었다. BFO 박막은 chemical solution deposition(CSD), ${ }^{8,9}$ pulsed laser deposition(PLD), ${ }^{10)} \mathrm{MOCVD}^{11}$ 및 sputtering $^{12)}$ 등에 의해 제조되었는데 이들 방법들에 의해 제조된 박 막들은 큰 잔류분극값과 낮은 결정화온도 등의 장점을 보 였다. 그러나 많은 연구자들은 $\mathrm{BFO}$ 박막이 결함들과 비 화학양론비에 의해 낮은 저항값을 가져 누설전류가 큼을 지적하여왔다. 즉, 큰 누설전류의 원인이 +3 이온으로 존 재해야 하는 $\mathrm{Fe}$ 이온이 +2 이온으로 전이 되어 공간 전하 의 불균형을 가져오고 이로 인한 산소 공공의 생성 때 문으로 보고된다. ${ }^{13)} \mathrm{BFO}$ 의 누설전류를 감소시키기 위하 여 $\mathrm{Mn}, \mathrm{La}$ 등으로 $\mathrm{A}$ 와 $\mathrm{B}$ 자리의 $\mathrm{Bi}$ 와 $\mathrm{Fe}$ 원소를 치환 하는 방법이 연구되고, 다양한 방법에 의해 $\mathrm{BFO}$ 박막 을 제조하려는 연구가 진행되고 있다. 보통 실온에서 측 정한 $\mathrm{BFO}$ 박막의 분극-전기장 $(\mathrm{P}-\mathrm{E})$ 이력곡선은 큰 누설 전류성분으로 인하여 포화되지 않으며, 전기적 성질은 조 성 및 미세구조 등에 의해 변화되는 특성을 보인다. $\mathrm{BFO}$ 박막의 제조방법은 주로 조성이 비교적 목표조성과 잘 일 치하는 CSD 및 PLD에 의해 많은 연구가 진행되었다. 
Table 1. Preparation conditions for $\mathrm{BiFeO}_{3}$ thin films.

\begin{tabular}{cc}
\hline Target-substrate distance & $60 \mathrm{~mm}$ \\
Substrate & $\mathrm{p}-\mathrm{Si}(100), \mathrm{Pt} / \mathrm{TiO}_{2} / \mathrm{Si}$ \\
Base pressure of chamber & $5 \times 10^{-6} \mathrm{Torr}$ \\
Deposition pressure & $10 \sim 70 \mathrm{mTorr}$ \\
R.F. power & $200 \mathrm{~W}$ \\
Sputtering gas (Ar: $\left.\mathrm{O}_{2}\right)$ & $1: 3$ \\
Substrate temperature & Room temp. \\
Annealing temperature & $450 \sim 550^{\circ} \mathrm{C}$ \\
\hline
\end{tabular}

본 연구에서는 r.f. magnetron sputtering법에 의해 $\mathrm{BFO}$ 박막을 제조하였으며 $\mathrm{BFO}$ 박막의 조성 및 미세구조의 변화에 영향을 미치는 증착압력 및 열처리의 효과를 파 악하고자 하였으며 이에 따른 전기적특성의 변화를 확인 하고 이들의 상관관계를 연구하였다.

\section{2. 실험 방법}

$\mathrm{Si}$ 기판위에 $\mathrm{BiFeO}_{3}$ 박막을 증착하기 위하여 r.f. magnetron sputtering법을 사용하였다. BFO 타겟은 고순 도(>99.9\%)의 $\mathrm{Bi}_{2} \mathrm{O}_{3}$ 와 $\mathrm{Fe}_{2} \mathrm{O}_{3}$ 분말을 이용하여 분말소결 법에 의해 제조하였다. $\mathrm{BFO}$ 박막의 전기저항을 향상시 키기 위하여 타겟 제조 시 $\mathrm{Mn} 5 \%$ 로 $\mathrm{Fe}$ 를 치환하였다. 스퍼터링 챔버를 $5 \times 10^{-6} \mathrm{Torr}$ 로 배기한 후, 증착가스 $(\mathrm{Ar} /$ $\mathrm{O}_{2}$ )를 1:3의 비율로 주입하였으며 타겟은 조성의 균질성 확보와 표면의 오염물을 제거하기 위하여 10 분 동안 선 스퍼터링 하였다. 증착압력과 열처리온도를 변수로 하여 $\mathrm{BFO}$ 박막을 제조하였는데 증착압력의 효과를 파악하기 위하여 $10 \mathrm{mTorr}$ 이상이 되도록 일정량의 가스를 흘리 면서 메인밸브의 개폐를 통해 조절하였고 열처리는 다양 한 온도의 질소분위기에서 5 분 동안 진행하였다. 상세한 증착조건은 Table 1에 나타내었다.

제조된 박막의 결정구조는 $\mathrm{Cu} \mathrm{K \alpha}$ radiation과 $\mathrm{Ni}$ 필 터를 사용한 X-ray 회절장치(XRD, Panalytical X'pert pro)를, 박막의 미세구조와 조성은 주사전자현미경(SEM$\mathrm{EDX}, \mathrm{Jeol}, \mathrm{JSM}-6700 \mathrm{~F})$ 을 이용하여 분석하였다. 전기적 특성을 측정하기 위해 백금이 코팅된 $\mathrm{Si}$ 기판위에 $\mathrm{BFO}$ 막을 제조한 후 상부전극으로 $100 \mu \mathrm{m}$ 의 직경을 갖는 백 금을 약 $100 \mathrm{~nm}$ 의 두께로 $\mathrm{dc}$ sputtering법으로 증착하여 $\mathrm{Pt} / \mathrm{BFO} / \mathrm{Pt} / \mathrm{TiO}_{2} / \mathrm{Si}$ 구조를 갖는 $\mathrm{MIM}$ (metal-insulator metal) 캐패시터를 제작하였다. 유전상수 및 유전손실계 수의 주파수 특성(C-F)은 impedance gain phase analyzer (Hewlett-Packard 4194A)를 이용하였고, 누설전류특성(JE)은 picoammeter(Hewlett-Packard 4140B) 이용하여 측 정하였다. $\mathrm{P}-\mathrm{E}$ (polarization -electric field) 이력특성은 ferroelectric test system(Radiant Technologies, RT66A) 을 이용하여 측정하였다.

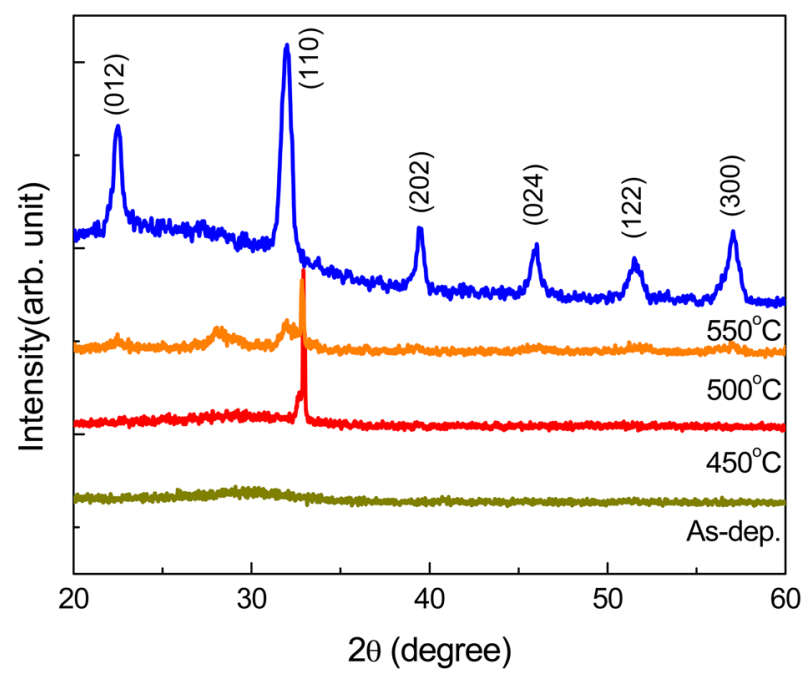

Fig. 1. XRD patterns of $\mathrm{BiFeO}_{3}$ films prepared on $\mathrm{Si}$ substrate as a function of the annealing temperature.

\section{3. 결과 및 고찰}

Fig. 1은 $50 \mathrm{mTorr}$ 의 증착압력과 상온에서 증착한 $\mathrm{BFO}$ 박막들을 $50 \mathrm{sccm}$ 의 $\mathrm{N}_{2}$ 가스를 흘리면서 5 분 동안 450 , $500,550{ }^{\circ} \mathrm{C}$ 에서 열처리한 시편의 $\mathrm{XRD}$ 회절패턴을 보 인다. $\mathrm{CSD}^{9}$ 에 의해 제조된 $\mathrm{BFO}$ 막의 경우, $350{ }^{\circ} \mathrm{C}$ 의 산소분위기 열처리에서 조차 결정화 되는 결과를 보이기 도 했으나 다수의 연구에서 $\mathrm{Bi}_{2} \mathrm{O}_{3}, \mathrm{Bi}_{2} \mathrm{Fe}_{4} \mathrm{O}_{9}, \mathrm{Bi}_{36} \mathrm{Fe}_{2} \mathrm{O}_{57}$ 등과 같은 2 차상을 제거하기 위해 $500{ }^{\circ} \mathrm{C}$ 이상의 온도에 서 열처리가 진행되었다. ${ }^{14-15)}$ 상온증착 및 $450{ }^{\circ} \mathrm{C}$ 에서 열 처리한 박막의 경우, 기판피크를 제외하고 $\mathrm{BFO}$ 피크는 보이지 않아 결정화가 진행되지 않았음을 알 수 있다. $550{ }^{\circ} \mathrm{C}$ 에서 열처리한 박막은 $500{ }^{\circ} \mathrm{C}$ 에서 열처리 한 박막 보다 큰 회절 강도를 갖는 $\mathrm{BFO}$ 의 피크들을 보이는데, 이는 열처리온도 증가에 따른 결정화도의 증가에 기인한 다고 할 수 있다. $550{ }^{\circ} \mathrm{C}$ 에서 열처리된 박막의 경우, 이 차상의 피크는 관찰되지 않으며 회절피크들은 능면정의 $\mathrm{R} 3 \mathrm{c}$ 구조와 잘 일치한다.

Fig. 2는 열처리 전 및 $450,500,550{ }^{\circ} \mathrm{C}$ 에서 열처리 한 $\mathrm{BFO}$ 박막들의 $2 \mu \mathrm{m} \times 2 \mu \mathrm{m}$ 면적에 대한 $\mathrm{AFM}$ 이미 지이다. 박막은 열처리온도가 증가함에 따라 박막의 $\mathrm{rms}$ (root mean square) 거칠기와 결정립도가 증가하는 결과를 보였다. 열처리 전 및 $450,500,550{ }^{\circ} \mathrm{C}$ 에서 열처리한 박막들의 $\mathrm{rms}$ 거칠기는 각각 $2.4,12.6,18.4,47.3 \mathrm{~nm}$ 를 보였다. 이는 Fig. 1의 XRD 분석결과에서 예측할 수 있 는 것처럼 열처리 온도 증가에 따른 결정화도의 증가 및 결정립 크기의 증가 때문이라 할 수 있다. 상온에서 증 착한 박막의 경우 결정립을 관찰하기 어려운 비정질의 형 상을 보이며 $550{ }^{\circ} \mathrm{C}$ 에서 열처리한 박막의 경우 다른 온 도에서 열처리한 박막보다 결정립도가 크다. 열처리온도 

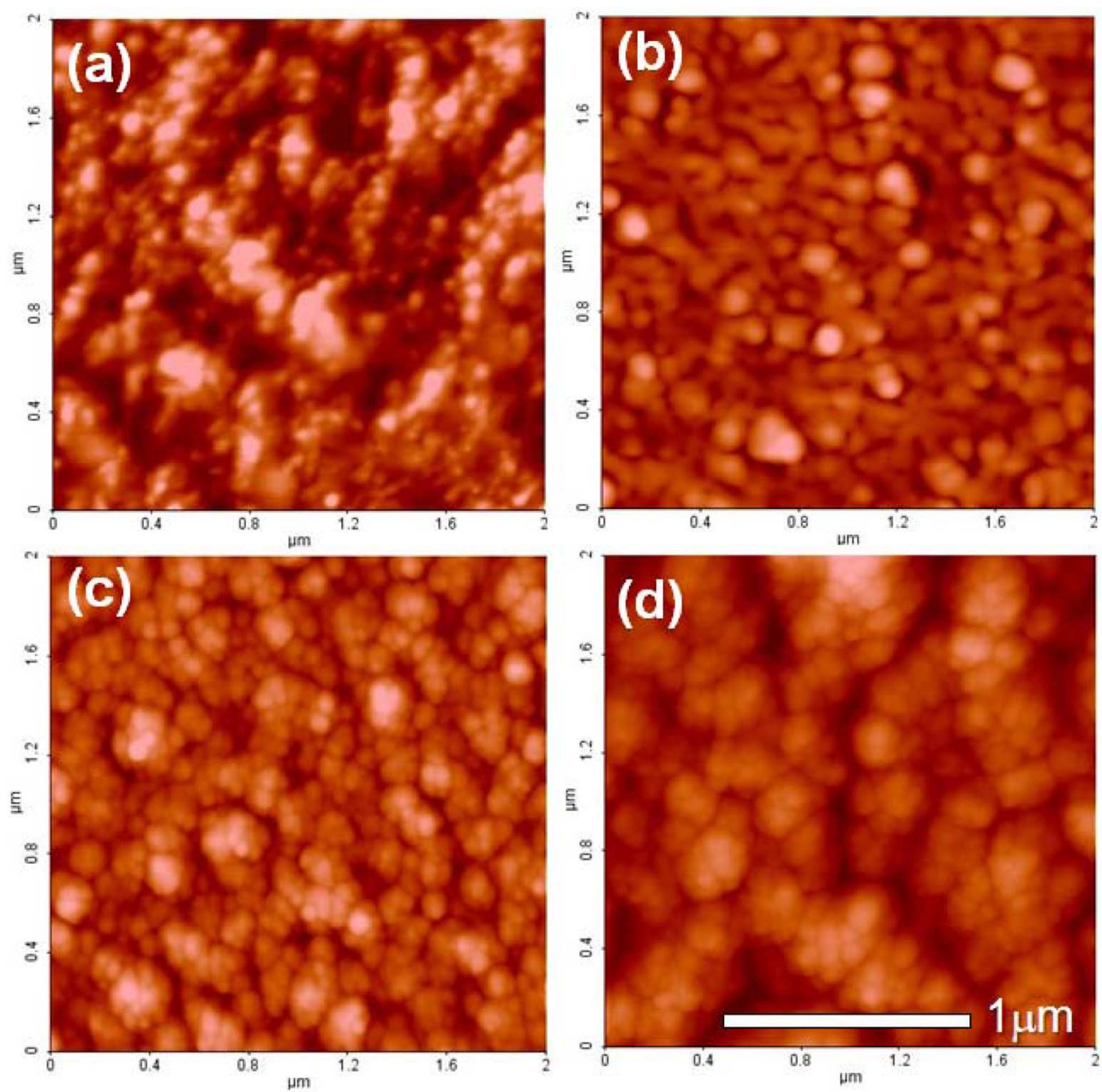

Fig. 2. $\mathrm{AFM}$ images of $\mathrm{BiFeO}_{3}$ thin films annealed at various temperature; (a) As-dep., (b) $450{ }^{\circ} \mathrm{C}$, (c) $500{ }^{\circ} \mathrm{C}$ and (d) $550{ }^{\circ} \mathrm{C}$.

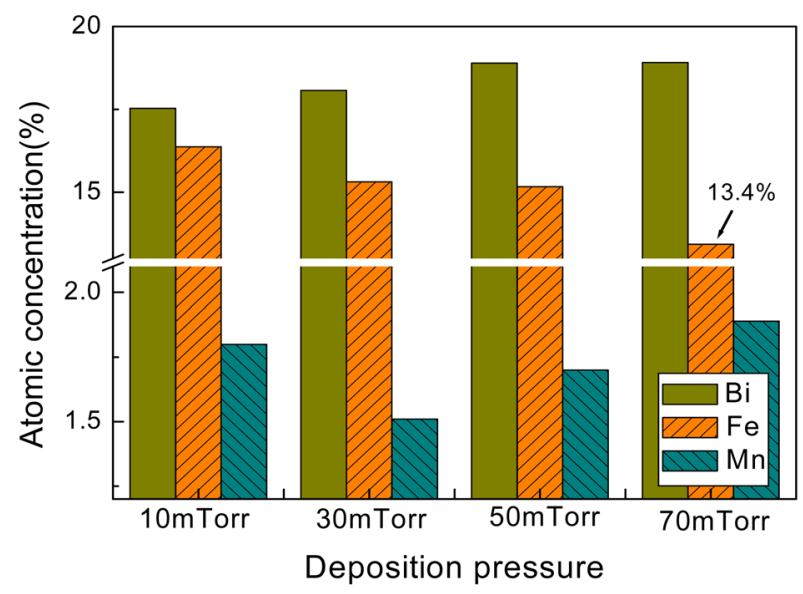

Fig. 3. Composition of $\mathrm{BiFeO}_{3}$ thin films deposited with various pressure from 10 to $70 \mathrm{mTorr}$.

가 증가함에 따라 결정립들은 클러스터의 형태로 성장하 며, 클러스터 또한 크게 성장하였다. 이러한 결과는 열
처리온도가 증가함에 따라 표면원자의 이동도가 증가함 으로 인해 박막의 결정화도가 증가하고 표면 거칠기가 증 가한다는 보고 ${ }^{16)}$ 와 일치한다고 할 수 있다. 이결과는 표 면거칠기가 결정화도에 따라 크게 영향 받음을 의미한다.

Fig. 3은 스퍼터링에 의해 $\mathrm{BFO}$ 박막을 증착 시 증착 압력을 10 70 mTorr로 변화시키며 증착압력에 따른 $\mathrm{Bi}$, $\mathrm{Fe}, \mathrm{Mn}$ 의 조성 변화를 보이는 $\mathrm{EDX}$ 결과이다. $(\mathrm{Fe}+\mathrm{Mn}) /$ $\mathrm{Bi}$ 비는 증착압력에 따라 변화를 보이며 $10,30,50$, $70 \mathrm{mTorr}$ 의 증착압력에서 각각 $1.1,1.05,0.9,0.82$ 를 보 였다. 즉, 증착압력이 증가함에 따라 $(\mathrm{Fe}+\mathrm{Mn}) / \mathrm{Bi}$ 의 감소 가 일어난다. 상대적인 조성비로 볼 때 $\mathrm{Bi}$ 는 증착압력이 증가함에 따라 증가하고, $\mathrm{Fe}$ 는 반대로 감소하는 경향을 보인다. 화합물의 경우 순금속의 경우와 스퍼터링 현상 이 상이하며, 높은 산소분압에서 $(\mathrm{Fe}+\mathrm{Mn}) / \mathrm{Bi}$ 비의 감소 는 $\mathrm{Fe}$ 산화물의 형성으로 인한 $\mathrm{Fe}$ 의 스퍼터링률(sputter yield)의 감소에 기인한다고 할 수 있다. $\mathrm{BFO}$ 박막의 조 성비를 고려할 때, $\mathrm{Ar}: \mathrm{O}_{2}$ 의 비가 $1: 3$ 인 가스비에서 $30 \sim 50 \mathrm{mTorr}$ 의 증착압력 범위가 적합함을 보였다. 

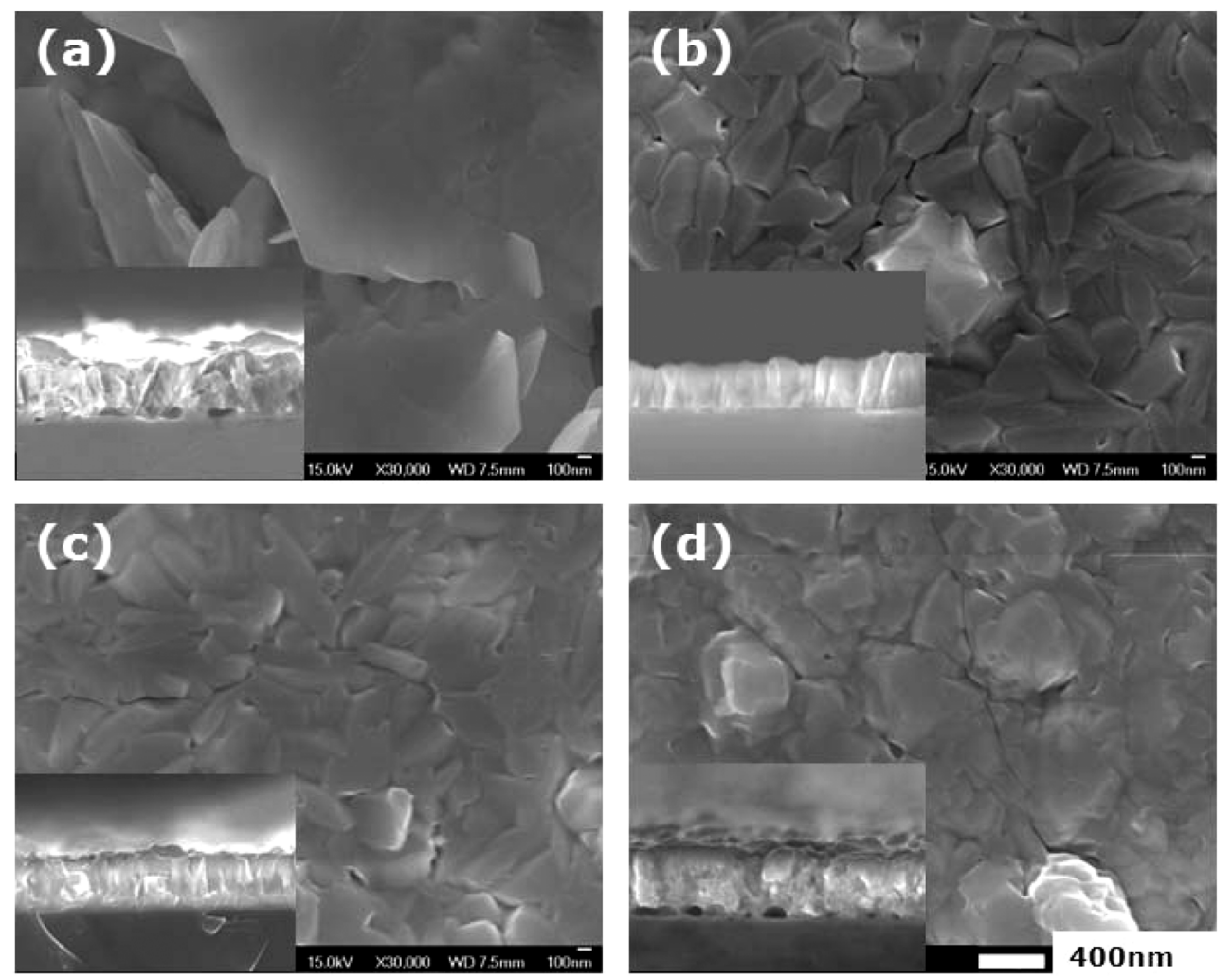

Fig. 4. $\mathrm{SEM}$ images of $\mathrm{BiFeO}_{3}$ thin films prepared as a function of deposition pressure; (a) 10 mTorr, (b) 30 mTorr, (c) $50 \mathrm{mTorr}$ and (d) 70 mTorr.
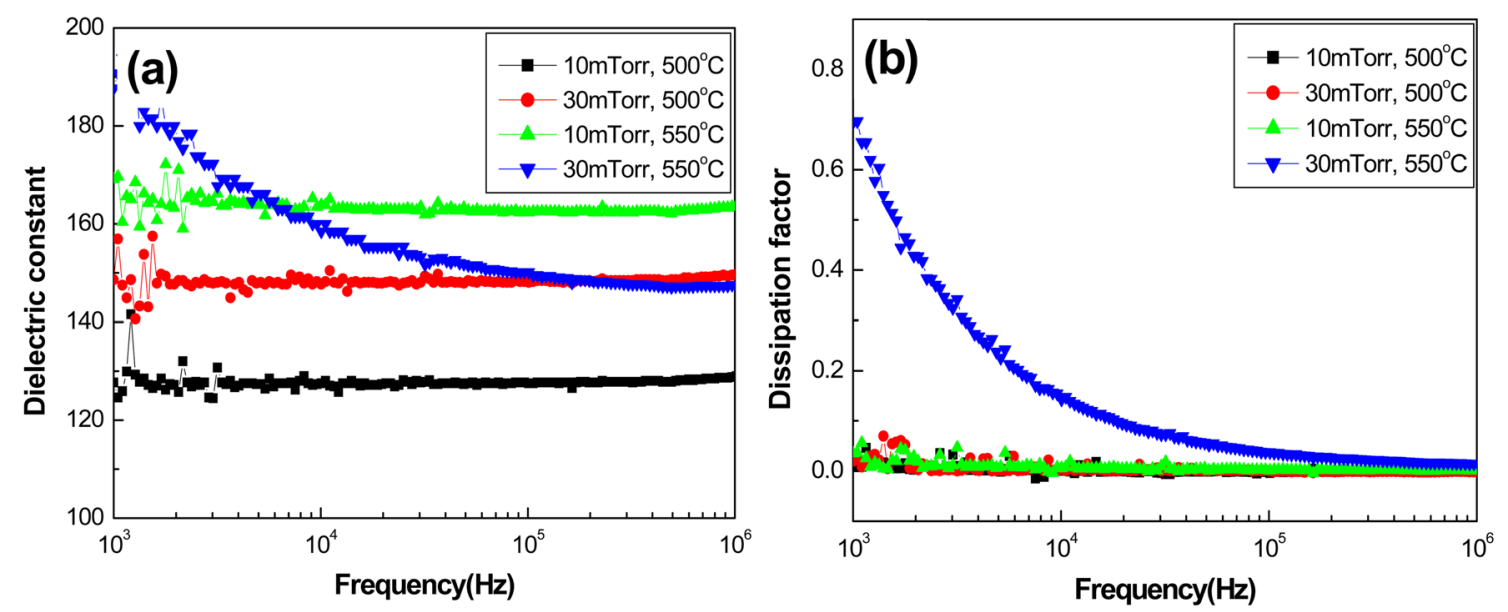

Fig. 5. Deposition pressure and annealing temperature dependence of the (a) dielectric constant and (b) dissipation factor of $\mathrm{BiFeO}_{3}$ films.

Fig. 4는 증착압력을 10 70 mTorr로 조절하여 제조한 후 $550{ }^{\circ} \mathrm{C}$ 에서 열처리한 $\mathrm{BFO}$ 박막의 $\mathrm{SEM}$ 이미지이며 삽입이미지는 각 시편의 단면형상을 보이고 있다. 표면 형상 및 결정립도가 증착압력에 따라 변화하는 모습을 보 이며 $10 \mathrm{mTorr}$ 에서 증착된 시편의 경우, 불규칙적인 판 상의 결정립형태를 보이며 특정 방향성 없이 불규칙적으 로 성장함을 단면이미지를 통해서 확인할 수 있다.
$30 \mathrm{mTorr}$ 에서 증착된 박막의 경우 한쪽방향으로 신장된 결정립들로 구성되어 있으며 기판에 수직한 방향으로의 주상정 성장을 보인다. $50 \mathrm{mTorr}$ 에서의 박막은 $30 \mathrm{mTorr}$ 에서 증착한 막과 결정립형상은 유사하나 결정립도가 증 가하고 더 치밀한 구조를 갖는다. $70 \mathrm{mTorr}$ 에서의 막은 신장된 결정립들의 모습은 사라지고 치밀한 표면형상으 로의 변화를 보인다. 또한 $70 \mathrm{mTorr}$ 의 박막에서는 본 논 


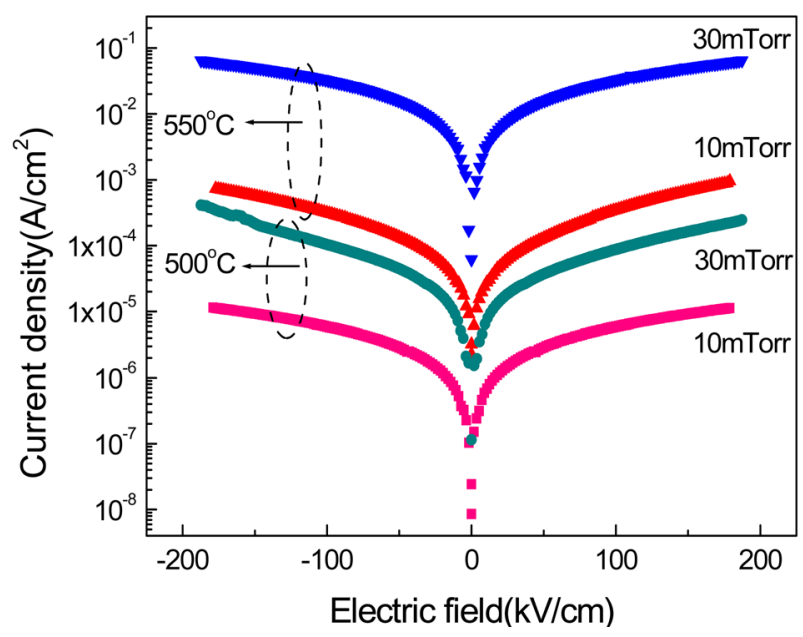

Fig. 6. J-E curves of $\mathrm{BiFeO}_{3}$ films annealed at 500 and $550{ }^{\circ} \mathrm{C}$.

문에 보이지 않았으나 $\mathrm{EDX}$ 분석결과 중간에 $\mathrm{Bi}$ 를 다량 함유한 2차상의 입자들이 확인되었다. 증착압력에 따라 기판에 도달하는 입자들의 운동에너지의 변화로 표면형 상이 변화될 수 있으나 Fig. 4의 박막들의 경우 조성비 의 변화에 의한 영향이 더 큰 것으로 판단된다.

Fig. 5는 $10 \mathrm{mTorr}$ 와 $30 \mathrm{mTorr}$ 에서 증착 후 500 및 $500{ }^{\circ} \mathrm{C}$ 에서 열처리 한 박막의 주파수에 따른 유전상수(a) 와 유전손실(b)의 변화를 보이는 그림이다. $1 \mathrm{kHz}$ 에서 $1 \mathrm{MHz}$ 의 주파수 영역에서 유전특성을 측정하였다. 박막 들의 유전상수는 증착압력 및 열처리 온도가 높을수록 유 전상수가 증가하는 경향이 있으며, 박막들의 유전상수는 $1 \mathrm{kHz}$ 에서 127 에서 187 의 값을 보였다. $30 \mathrm{mTorr}$ 에서 증 착 후 $550^{\circ} \mathrm{C}$ 에서 열처리한 박막의 경우 $1 \mathrm{kHz}$ 에서 가 장 큰 값을 보이는데 이는 그림 (b)에서 보인 것처럼 유 전손실의 증가가 주원인이라 할 수 있다. 증착압력 및 열 처리온도 증가에 따른 유전상수의 증가는 $\mathrm{BFO}$ 박막의
결정화도 및 결정립도의 증가 때문이라 할 수 있다. 유 전상수는 $\mathrm{CSD}$ 및 $\mathrm{PLD}$ 에 의해 제조된 박막의 경우와 유 사하거나 높은 값을 보인다. ${ }^{8,12)}$ Fig. 5(b)는 유전손실의 변화를 보이는데, $1 \mathrm{kHz}$ 에서 $69 \%$ 의 높은 유전손실을 보 이는 $30 \mathrm{mTorr}$ 에서 증착 후 $550^{\circ} \mathrm{C}$ 에서 열처리한 박막 의 경우를 제외하고 나머지 박막들은 $2.0 \sim 3.5 \%$ 의 양호 한 유전손실값을 보인다. 박막의 유전손실에 영향을 주는 구조적 결함은 박막과 전극 사이의 계면이나 표면에서 격 자붕괴 혹은 표면형상에 의해 유발되는 것으로 보고된다. ${ }^{17)}$ $30 \mathrm{mTorr}$ 및 $550{ }^{\circ} \mathrm{C}$ 열처리조건의 박막에서의 높은 유전 손실은 높은 증착압력과 열처리온도로 인한 박막표면 및 전극계면 특성의 열화와 관련이 있는 것으로 볼 수 있다.

Fig. 6은 $\mathrm{Pt} / \mathrm{TiO}_{2} / \mathrm{Si}$ 기판위에 압력을 달리하여 $\mathrm{BFO}$ 박막을 증착 후 500 및 $500{ }^{\circ} \mathrm{C}$ 에서 열처리 한 박막의 상온에서 측정한 전류밀도-전계(J-E) 특성을 보인다. 박 막들의 누설전류 밀도는 $\mathrm{Mn}$ 으로 $\mathrm{Fe}$ 를 일부 치환했음에 도 불구하고 큰 누설전류밀도를 나타내었다. 증착압력 및 열처리온도의 증가에 따라 $\mathrm{BFO}$ 박막들의 전류밀도는 증 가하는 경향을 보이는데 이는 $\mathrm{Pt} / \mathrm{BFO} / \mathrm{Pt}$ 계면구조의 열 화에 기인하는 것으로 사료된다. 본 논문에는 보이지 않 았으나 실험 결과 모든 박막에서 누설전류와 유전손실은 동반하여 증감하는 경향을 보였다. 증착압력의 증가에 따 라 누설전류가 증가하는데 이보다 열처리온도의 증가로 인한 누설전류의 증가폭이 더 큼을 보였다. $550^{\circ} \mathrm{C}$ 에서 열처리한 박막의 경우, 10 및 $30 \mathrm{mTorr}$ 의 압력에서 증 착한 박막은 $100 \mathrm{kV} / \mathrm{cm}$ 의 전계에서 각각 $3.4 \times 10^{-4}$ 및 $3.2 \times 10^{-2} \mathrm{~A} / \mathrm{cm}^{2}$ 로 매우 높은 누설전류를 보였다. 가장 작 은 값을 보이는 $10 \mathrm{mTorr}$ 에서 증착 후 $500{ }^{\circ} \mathrm{C}$ 에서 열처 리한 박막의 경우 $100 \mathrm{kV} / \mathrm{cm}$ 의 전계에서 $5.9 \times 10^{-6} \mathrm{~A} / \mathrm{cm}^{2}$ 값을 보여 $\mathrm{CSD}^{8,9}$ 에 의해 제조된 막보다 작은값을 보였다.

Fig. 7은 $\mathrm{Pt} / \mathrm{TiO}_{2} / \mathrm{Si}$ 기판위에 $30 \mathrm{mTorr}$ 의 압력에서 증 착한 $\mathrm{BFO}$ 박막의 상온에서 측정한 전기분극-외부전계
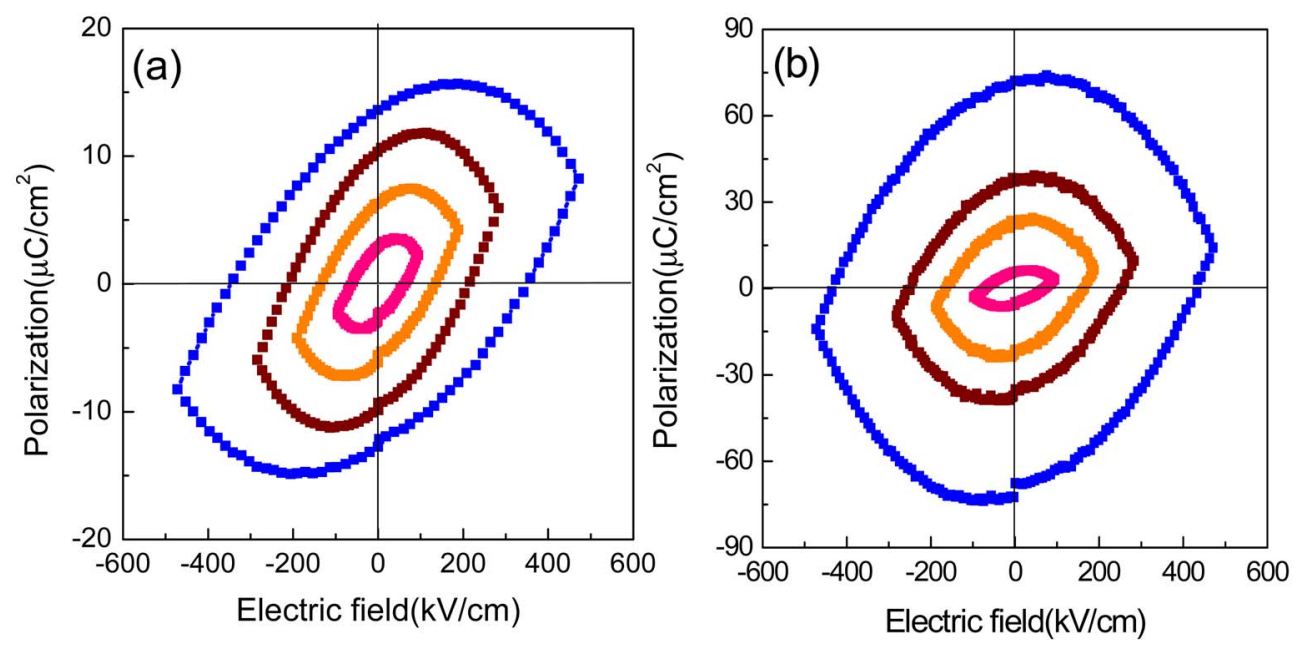

Fig. 7. polarization(P)-electric field(E) hysteresis behavior of $\mathrm{BiFeO}_{3}$ films annealed at (a) 500 and (b) $550{ }^{\circ} \mathrm{C}$. 
(P-E) 이력 특성이며, (a)와 (b)는 각각 500 및 $550{ }^{\circ} \mathrm{C}$ 의 질소분위기에서 5 분 동안 열처리한 박막의 특성을 나타 내었다. 두 경우, BFO 박막의 P-E 곡선은 포화되지 않 는 이력곡선을 보인다. 이러한 원인은 Fig. 6.에서 보인 것처럼 상대적으로 높은 누설전류에 기인한다. 누설전류 가 큰 박막의 경우 포화되지 않는 변형된 P-E 곡선이 일반적으로 관찰된다. $550{ }^{\circ} \mathrm{C}$ 에서 열처리한 박막(b)의 경 우 $500{ }^{\circ} \mathrm{C}$ 에서 열처리한 박막(a)에 비해 크게 변형된 PE곡선을 보이는데 이는 Fig. 6 에서 보인 바와 같이 더 높은 누설전류 때문이라 할 수 있다. $500{ }^{\circ} \mathrm{C}$ 에서 열처리 한 (a)의 박막의 경우 $10 \mathrm{~V}$ 의 인가전압 $(470 \mathrm{kV} / \mathrm{cm})$ 에서 잔류분극 $(2 \mathrm{Pr})$ 과 항전계 $(\mathrm{Ec})$ 값은 각각 $26.4 \mu \mathrm{C} / \mathrm{cm}^{2}$ 과 $338 \mathrm{kV} / \mathrm{cm}$ 를 보였다. 양호한 P-E 특성을 얻기 위해서는 누설전류를 감소시키기 위한 연구가 필요하며 본 연구범 위에서는 $\mathrm{Mn}$ 치환의 효과보다 표면 및 계면 미세구조 의 안정화가 더 필요한 것으로 판단된다.

\section{4. 결 론}

본 연구에서는 $\mathrm{Mn}$ 으로 부분 치환된 $\mathrm{BFO}$ 박막을 r.f. magnetron sputtering을 이용하여 증착하고, 제조시 증착 압력과 열처리 온도를 변수로 하여 이에 따른 전기적 특 성을 평가하였다. 실험을 통해 증착압력과 열처리 온도 가 $\mathrm{BFO}$ 의 전기적 특성에 크게 영향을 미침을 알 수 있 었다. $\mathrm{N}_{2}$ 가스 분위기에서 5 분 동안 열처리한 $\mathrm{BFO}$ 박 막들은 $500^{\circ} \mathrm{C}$ 이상에서 결정화가 진행되었고 열처리온도 가 증가함에 따라 결정립도 및 표면 거칠기가 증가하였 다. 증착압력이 증가함에 따라 $(\mathrm{Fe}+\mathrm{Mn}) / \mathrm{Bi}$ 의 감소가 일 어났으며 결정립도가 증가하였다. 열처리온도 및 증착압 력에 따라 유전상수는 $1 \mathrm{kHz}$ 에서 127 187을, 누설전류 밀도는 $100 \mathrm{kV} / \mathrm{cm}$ 의 전계에서 $3 \times 10^{-2} \sim 5 \times 10^{-6} \mathrm{~A} / \mathrm{cm}^{2}$ 를 나 타내었다. 박막들의 P-E 특성은 큰 누설전류로 인해 상 온에서 포화되지 않았으며 $500{ }^{\circ} \mathrm{C}$ 에서 열처리한 $\mathrm{BFO}$ 박 막은 $470 \mathrm{kV} / \mathrm{cm}$ 에서 $26.4 \mu \mathrm{C} / \mathrm{cm}^{2}$ 의 잔류분극값을 보였다. 증착압력과 열처리온도가 박막의 표면 및 계면특성에 영 향을 주고 이는 전기적 특성에 영향을 미치므로 r.f. magnetron sputtering에 의해 BFO 박막 제조시 낮은 누 설전류와 양호한 P-E 특성을 얻기 위하여 저온결정화가 필요하며 적정한 증착압력이 필요하다.

\section{감사의 글}

이 논문은 상주대학교 (2007년도) 학술연구지원금에 의 해 연구되었음.

\section{참 고 문 헌}

1. J. Dho, C.W. Leung, J. L. M. Driscoll and M.G. Blamire, J. Cryst. Growth, 267, 548 (2004).

2. W. M. Zhu and Z. G. Ye, Ceram. Int., 30, 1435 (2004).

3. J. Wang, J.B. Neaton, H. Zheng, V. Nagarajan, S.B. Ogale, B. Liu, D. Viehland, V. Vaithyanathan, D.G. Schlom, U.V. Wagmare, N.A. Spaldin, K.M. Rabe, M. Wuttig and R. Ramesh, Science, 299, 1719 (2003).

4. T. Kimura, T. Goto, H. Shintani, K. Ishizaka, T. Arima and Y. Tokura, Nature, 426, 55 (2003).

5. F. Kubel and H. Schmid, Acta Crystallogr., B 46, 698 (1990).

6. J. M. Moreau, C. Michel, R. Gerson and W. J. James, J. Phys. Chem. Sol., 32, 1315 (1971).

7. W. Eerenstein, F. D. Morison, J. Dho, M. G. Blamire, J. F. Scott and N. D. Mathur, Science, 307, 1203 (2005).

8. H. Uchida, R. Ueno, H. Nakaki, H. Funakubo and S. Koda, Jpn. J. Appl. Phys., 44, L561 (2005).

9. C. F. Chung and J. M. Wu, Electrochem. Solid-state Lett. 8, F63 (2005).

10. H. Bea, M. Bibes, A. Barthelemy, K. Bouzehouane, E, Jacquet, A. Khodan, J. P. Contour, S. Fusil, F. Wyczisk, A. Forget, D. Lebeugle, D. Colson and M. Viret, Appl. Phys. Lett., 87, 072508 (2005).

11. W. Tian, V. Vaithyanathan, D. G. Schlom, Q. Zhan, S. Y. Yang, Y. H. Chu and R. Ramesh, Appl. Phys. Lett., 90, 172908 (2007).

12. C. C. Lee and J. M. Wu, Appl. Surf. Sci., 253, 7069 (2007).

13. Y. P. Wang, L. Zhou, M. F. Zhang, X. Y. Chen, J. M. Liu and Z. G. Liu, Appl. Phys. Lett., 84, 1731 (2004).

14. S. K. Singh and H. Isiwara, Jpn. J. Appl. Phys., 44, L734 (2005).

15. J. K. Kim, S. S. Kim and W. J. Kim, Mater. Lett., 59, 4006 (2005).

16. S. T. Tay, X. H. Jiang, C. H. A. Huan, T. S. Wee and R. Liu, J. Appl. Phys., 88, 5928 (2000).

17. V. M. Ferreira, J. L. Baptista, S. Kamba and J. Petzelt, J. Mater. Sci., 28, 5894 (1993). 